\title{
PROCESS OF TEACHING READING IN MIDDLE AND HIGH SCHOOLS - AN APPROACH OF PROGRAMS THAT WORK
}

\author{
ZAMIRA MËRKURI \\ Eqrem Çabej University, Gjirokastër, Albania
}

\begin{abstract}
The ability to read, write, speak, listen, and think effectively - enables adolescents to learn and to communicate clearly in and out of school. Adolescents need to have strong reading skills so that they can understand academic content, communicate in a credible way, participate in cultural communities, and negotiate the world. The standards movement asserts that all students should understand content at deeper, more complex levels than have been advocated previously. A variety of teaching and learning strategies have been shown to be effective in assisting adolescent learners to develop their capacity as readers. Nevertheless, according to this paper, there is an "everdeepening crisis in adolescent reading." (Department of Education, "Eqrem Çabej" University of Gjirokastra 2004). The paper considers how effective content-based reading instruction can be brought to life in the classroom in ways that will make a positive difference for learners.

UDC \& KEYWORDS
\end{abstract}

- UDC: 377 - Reading instructions - Struggling readers " Schoolwide effort a Comprehensive reading approach = Effective literacy instruction

\section{INTRODUCTION}

An effective, school-wide model for teaching reading should include a two-prong approach:

- A plan for providing reading instruction to good readers (close to grade level or above), and

- a plan for providing reading instruction to struggling readers.

Reading instruction for good readers should be delivered in regular content classes including history, English/language arts, science, and math. (Joftus, S. "Every child a graduate: A framework for an excellent education for all middle and high schools". 2002).

Reading instruction for struggling readers should be delivered partly in regular content classes, and partly in intervention settings including extended English/language arts blocks, and individual/small group settings.

A school-wide approach to reading instruction must involve all teachers in the development of the model and delivery of reading instruction (including regular content teachers and staff who work with special learners). It must also have strong, committed leadership that provides ongoing support and guidance for reading instruction. There is no single explanation for why some students have difficulty reading beyond grade five. Although adolescent reading problems are sometimes attributed to lack of study, motivation or attention, research in reading and literacy has shown that these issues are often secondary consequences of underlying problems, not the primary causes of poor reading (Peterson, C.L.; Caverly, D.C.; Nicholson, S.A.; O'Neil, S.; \& Cusenbary, S. "Building reading proficiency at the secondary level", 2000). In most cases, struggling readers have difficulty in one or more of the following:
1. Word recognition and decoding skills (i.e., phonemic awareness, phonics, and/or fluency).

2. Language processing ability at the word, sentence, or discourse level.

3. Vocabulary development.

4. Life experience, background knowledge of the reading topic.

5. Awareness of one's own comprehension processes (meta-cognition).

6. Comprehension and study strategies.

\section{The need for assessment}

The only way to determine the cause of an individual student's reading difficulty is through diagnostic assessment. (Moats, L. "When older kids can't read. Education Leadership", March 2001). Annual, reading assessments should be administered to all students. The assessments used for this purpose can be groupadministered, but should yield more then a simple gradelevel score. They should provide a first-round indication of individual ability in specific components of reading (e.g., word identification, vocabulary, listening and reading comprehension, comprehension strategy skills). Based on the results of this initial assessment, two categories of readers can be identified: a) good readers and b) struggling readers.

Annual formal assessment of good readers is sufficient, coupled with the informal assessment information that content teachers gather while teaching students during the school year.

Struggling readers, however, require a second round of assessment that will yield specific diagnostic information about individual reading difficulties. The best assessments for this purpose can be group and/or individually administered, but they should be chosen because they yield the best diagnostic information. The results from this assessment drive instruction and determine specific reading instruction interventions for specific students. On-going assessment (formal and/or informal) is important throughout the school year to monitor progress and adjust intervention plans.

\section{Settings for reading instruction}

The attached graphic organizer titled "Middle/High School Comprehensive Reading Approach" illustrates a two-prong model for addressing the needs of good and struggling readers. As the chart indicates, general reading assessment identifies good and struggling readers.

An arrow connects good readers to the top row (Reading Instruction: All Students). The setting for this reading instruction is regular content classes, taught by content teachers.

For struggling readers, there are two arrows. One arrow connects them to the top row where they will receive the same reading instruction as good readers, in a classroom 


\section{PROCESS OF TEACHING READING IN MIDDLE AND HIGH SCHOOLS - AN APPROACH OF PROGRAMS THAT WORK}

setting that incorporates differentiated instruction and scaffolding to meet their specific needs. Inclusion teachers or paraprofessionals may be assigned to these content classes to assist in providing differentiated instruction.

The second arrow connects them to the bottom row (Intervention Programs: Struggling Readers). These students will receive a variety of intervention reading instruction based on their individual needs. Some students may need instruction in basic phonemic awareness or decoding skills. Some may need specific practice to develop fluency skills. Some may require instruction in language structures or vocabulary development, while others may need more practice with comprehension strategy instruction then is offered in regular content classes. The teachers providing intervention instruction and supplemental reading programs can be reading specialists, special education teachers, Title I teachers, and/or paraprofessionals. The intervention methods and materials may include specific supplemental reading programs, targeted intervention instruction, and/or reading intervention software.

Middle and high school administrators must make the acquisition of reading skills a priority and provide adequate time in the school schedule for reading instruction. They must also be willing to use flexible grouping patterns when scheduling students in order to implement a two-prong model for delivering reading instruction in both content classes and intervention settings.

\section{Professional development for all teachers}

To quote Louisa Moats, ("Teaching reading is rocket science" (Moats, 1999), one of three major findings on reading comprehension is that teaching reading comprehension strategies to students at all grade levels is complex.

Teachers must not only have a firm grasp of the content presented in text, but also must have substantial knowledge of the strategies themselves, of which strategies are most effective for different students and types of content and of how best to teach and model strategy use. Research indicates that teachers require extensive formal instruction in how to teach reading comprehension, preferably beginning as early as pre-service. (National Reading Panel, 2000). For many middle and high school content teachers who did not receive this instruction before they became teachers, the only way to receive this training is through current professional development.

\section{Professional development for reading intervention teachers}

Reading intervention teachers are responsible for evaluating assessment data, determining individual student service plans, identifying and choosing appropriate supplemental reading programs and intervention models, and monitoring student progress in addition to providing reading instruction. They must juggle these tasks within the context of middle and high school scheduling constraints and often with limited support staff. These teachers need a great deal of on-going professional development to keep up with all of the assessments, methods and materials, and supplemental programs that are available for struggling readers. They also need school-wide support and communication to help carry over what they are teaching into regular content classes.

\section{A complex, long-term effort}

There is no simple, one-size-fits-all model for improving reading achievement in middle and high schools. Each school has its own unique combination of administrators, teaching staff, student needs, community involvement, and resources that must be considered before a school-wide approach to reading instruction can be developed. A middle or high school must first determine the current status of reading needs and instruction at the school:

1. What assessments are currently used to identify good and struggling readers?

2. What assessments are used to identify specific needs of individual struggling readers? What reading instruction is already taking place in content classrooms, and what professional development do content teachers need to effectively address all reading components?

3. What reading interventions and supplemental reading programs are currently offered for struggling readers?

4. What information and professional development do the teachers of struggling readers need?

5. Is the scheduling process flexible enough to accommodate different grouping patterns for struggling readers?

As these questions suggest, a school must be willing to put the time into identifying what is already being done and what should be changed in order to more successfully improve student reading ability. Schools should establish a "Reading Evaluation Team" (Moats, L. \& Sedita, J. LETRS: "A road to reading comprehension", Longmont, CO: Sopris West. 2004) where administrators, content classroom teachers, and teachers who work with struggling readers are included. This team should coordinate the school-wide effort to assess current practices and gather input from everyone involved about what they think is needed in order to address the reading needs of their students. The Reading Team can also coordinate the gathering of information about the following topics:

1. What group and individual reading assessments are available, and which assessments would best meet the needs of our school?

2. What support and professional development do our content classroom teachers need in order to incorporate vocabulary, comprehension strategy, and study skill instruction into existing curriculum?

3. What support and professional development do content classroom teachers need in order to differentiate and scaffold their instruction to meet the needs of a wide variety of readers?

4. What support and professional development do the teachers who work with struggling readers need in order to use assessment data, determine individual student reading needs, and schedule intervention instruction time?

5. What knowledge and professional development do the teachers and paraprofessionals need about supplemental reading programs, intervention methods, and computer assisted software?

Once a school has answered these questions, it can identify appropriate components for a school-wide reading instruction model. The school must then prioritize each component, develop a time-table for addressing each component, and determine what resources are available to support each component. It is important to remember that assessments, professional development, and the purchase of instructional material are all interdependent. (Moats, L. (2004). LETRS Module 12: Using assessment to guide instruction. Longmont, CO: Sopris West). For example, an assessment plan will not do much good if teachers do not know what to do with the diagnostic information that assessment provides. 


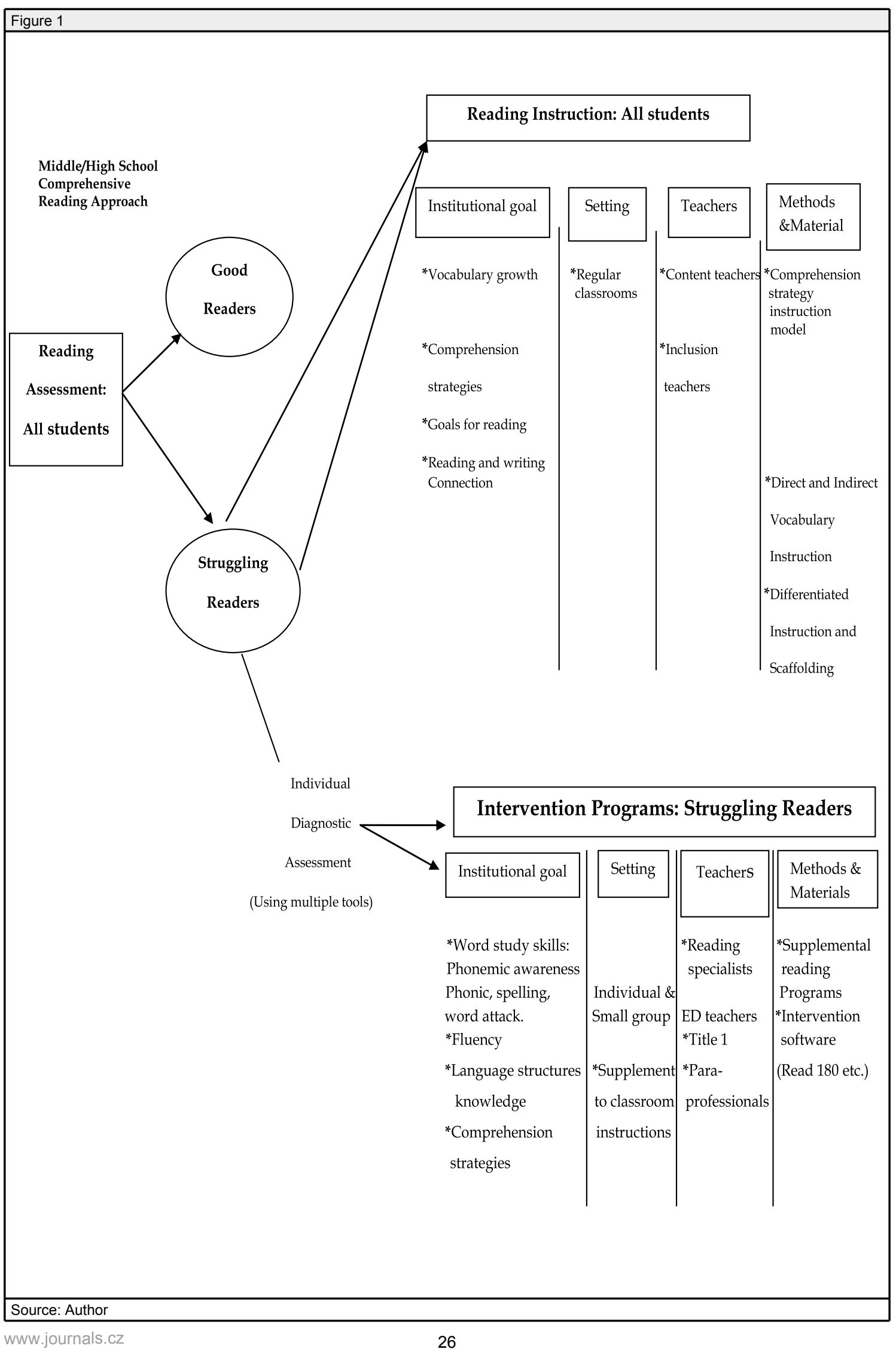




\section{PROCESS OF TEACHING READING IN MIDDLE AND HIGH SCHOOLS - AN APPROACH OF PROGRAMS THAT WORK}

Intervention instruction in comprehension, vocabulary or decoding skills will not be successful if content teachers do not also integrate that instruction into content classrooms. Teachers working with struggling readers may learn how to identify individual student needs, but they cannot successfully teach if the school has purchased inappropriate supplemental reading programs or materials.

\section{Conclusion}

The time, effort, and expertise necessary to develop a school-wide plan for providing effective reading instruction to all students present a challenge for most middle and high schools. The challenge is worth taking - there is an urgent need to improve the reading, writing and comprehension skills of middle and high school students. The most recent (Ministry of Education and Sciences, 2002 Statistics. National Assessment of Educational Progress (NAEP). ALB.). exams shows that 25 percent of eighth graders and 26 percent of twelfth graders in our country were reading at "below basic" levels in 2002; international comparisons of reading performance placed eleventh graders very close to the bottom, behind students from the other developing nations. There is a considerable number of fourth through twelfth graders whose chances for academic success are dismal because they are unable to read and comprehend the material in their textbooks (Sedita, J. "The Key Three Routine: Comprehension Strategy Instruction”, 2003, 2008).

Great attention has been paid over the past several years to increasing childhood education opportunities and reaching the national goal of making sure every child can read by the third grade. Some people believe that targeting early elementary reading has used limited resources at the expense of older students. The good news is that attention is beginning to focus on the reading needs of students in upper grades, and state and federal funding for adolescent literacy appears to be increasing. In the next several years, there will be more support for developing school-wide middle and high school reading initiatives. (Joftus, 2002; Rombeck, 2004).

We now also know more than ever before about effective literacy instruction for older students. (Kamil, M.L. (2004). Adolescents and literacy: Reading for the 21st century. Alliance for Excellent Education).

\section{REFERENCES}

1. Department of Education "Eqrem Çabej university of Gjirokastra (2004).

2. Joftus, S. (2002). Every child a graduate: A framework for an excellent education for all middle and high schools.

3. Peterson, C.L.; Caverly, D.C.; Nicholson, S.A.; O'Neil, S.; \& Cusenbary, S. (2000). Building reading proficiency at the secondary level.

4. Moats, L. (2001). When older kids can't read. Education Leadership, March 2001.

5. Moats, L. (1999). Teaching reading is rocket science.

6. National Reading Panel (2000). Report of the National Reading Panel: Teaching children to read, an evidence-based assessment of the scientific research literature on reading and its implications for reading instruction. National Institute of Child Health and Human Development.

7. Moats, L. \& Sedita, J. (2004). LETRS A road to reading comprehension. Longmont, CO: Sopris West.

8. Moats, L. (2004). LETRS Module 12: Using assessment to guide instruction. Longmont, CO: Sopris West.

9. Ministry of Education and Sciences, 2002 Statistics. National Assessment of Educational Progress (NAEP). ALB.
10. Sedita, J. $(2003,2008)$. The Key Three Routine: Comprehension Strategy Instruction.

11. (Joftus, 2002; Rombeck, 2004).

12. Kamil, M.L. (2004). Adolescents and literacy: Reading for the 21st century. Alliance for Excellent Education. 